\title{
The translation and cultural adaptation validity of the Actual Scope of Practice Questionnaire
}

Lina Younan, ${ }^{1}$ Michael Clinton, ${ }^{1}$ Souha Fares ${ }^{1}$ and Helen Samaha ${ }^{1}$

${ }^{1}$ Hariri School of Nursing, American University of Beirut, Beirut, Lebanon (Correspondence to: Lina Younan: lyı1@aub.edu.lb).

\begin{abstract}
Background: Information on the scope of nursing practice is urgently needed in the Eastern Mediterranean region to help policy makers and directors of nursing develop informed workforce plans.

Aims: This study aimed to validate the Arabic translation and cultural adaptation of the Actual Scope of Practice Questionnaire (A-ASCOP).

Methods: The process of translation and cultural validation adhered to WHO guidelines. The process involved forward translation, review by an expert panel, back-translation, pre-testing and cognitive interviewing.

Results: The clarity, meaningfulness and relevance of the first Arabic version of the A-ASCOP has been validated.

Conclusion: Subject to psychometric analysis, the A-ASCOP is suitable for use in Lebanon and countries of the Middle Eastern region.

Keywords: scope of practice; nursing; validity; transcultural; translation

Citation: Younan L; Clinton M; Fares S; Samaha H. The translation and cultural adaptation validity of the actual scope of practice questionnaire. East Mediterr Health J. 2019; 25(3):181-188 https://doi.org/10.26719/emhj.18.028

Received : 23/08/17; accepted : 27/03/18

Copyright (c) World Health Organization (WHO) 2019. Some rights reserved. This work is available under the CC BY-NC-SA 3.0 IGO license (https:// creativecommons.org/licenses/by-nc-sa/3.o/igo).
\end{abstract}

\section{Introduction}

Every healthcare profession has a scope of practice that determines the activities a member is authorized to perform subject to sufficient education and a current license to practice. The scope of nursing practice encompasses activities with a wide range of complexity that varies according to patients' physical, emotional, psychological and spiritual needs. The boundaries of nursing practice are usually set by a law that regulates the profession, commonly referred to as a "Practice Act". Studies have shown that patient safety quality of care, and cost-effectiveness are compromised when nurses perform activities beyond their knowledge and experience and when they are not permitted to work to their full scope of practice (1-3). Valid and reliable measures of the actual scope of nursing practice are required if policy-makers and nursing directors are to deploy the current workforce efficiently and plan effectively for the future.

In the Eastern Mediterranean Region (EMR) there is no Arabic instrument that measures the frequency of nursing activities and their levels of complexity. However, the Actual Scope of Nursing Practice questionnaire (ASCOP), developed by D'Amour et al. (4) following an extensive literature search and review of international regulatory requirements, may be suitable for use in the EMR. The ASCOP was developed in French and is also available in English, but this is the first Arabic version of the questionnaire. We used the Arabic version of the ASCOP, the Arabic Actual Scope of Nursing Practice Questionnaire (A-ASCOP), to survey nurses throughout Lebanon to determine their scope of practice and to identify whether they were working within or beyond the scope of practice appropriate to their level of nursing education. The purpose of this article is to describe how the A-ASCOP was developed.

\section{Background}

The 1997 nursing law referred to as Decree 1655 (5) distinguishes between three nursing levels: the "Professional Nurse" who is a holder of a Bachelor of Science in Nursing (BSN); the "Nurse", holder of a Baccalaureate Technique (BT) (3 years technical programme post 9th grade); and the "Nurse Assistant" who is trained in a hospital or a nursing school for 1 year (Appendix A). The same law was amended in 1982 to allow nurses holding a Technique Supérieur (TS) degree [3 years technical programme post BT] to work as "Professional Nurse". The functions executed by each category are delineated in decree 1655 as amended by Law \# 82/10. Decree 1655 is outdated because it does not refer to advanced nursing practice and does not differentiate clearly between the functions of the "professional nurse" (BS or TS) and those of the "nurse" (BT). Some hospitals are employing BT nurses to work as practical nurses, and others are employing them to work as registered nurses (Appendix B). This ambiguity in functions leaves nurses in Lebanon prone to over-utilize or under-utilize their skill sets.

Lebanese nurse leaders have responded to the omissions and ambiguities in Decree 1655 by drafting an updated practice act with three categories of nurse delineated by level of preparation: nurse specialist (Master of Science in Nursing), nurse (Bachelor of Science in Nursing), and nurse assistant (Baccalaureate 
Technique Certificate). The draft updated decree lists nursing activities corresponding with the three levels of preparation (6). Neither the updated practice act, nor the draft qualification and specific scopes of nursing practice have been approved due to the political situation in the country. Currently, the Order of Nurses in Lebanon (ONL) is in the process of refining the qualifications and job specifications of the three categories in the draft updated practice act.

The A-ASCOP will help the ONL to identify the activities undertaken most frequently by each category of nurse in Lebanon. The data will be used to develop a comprehensive scope of practice for nurses in Lebanon that will contribute to patient safety and cost-effective use of the nursing workforce.

\section{Methodology}

\section{Instrument of Data Collection}

The ASCOP questionnaire includes 26 activities rated on a six category Likert-type scale (1: Never; 2 : Very rarely; 3: Sometimes; 4: Frequently; 5: Almost always; 6: Always). The activities are clustered into six dimensions covering the full scope of nursing practice as follows: Assessment and care planning, Patient and family teaching, Care coordination and communication, Staff integration and supervision, Patient safety and quality of care, and Updating and utilization of knowledge. These activities were grouped into three levels of complexity by a panel of expert nurses (4). Level 1 or low complexity activities are those any $\mathrm{RN}$ including a beginner is expected to perform. Level 2 or moderately complex activities are those expected of an experienced RN irrespective of level of professional education. Level 3 or high complexity activities are those expected to be performed by an experienced RN holding a BS degree (4)

The original English instrument was tested in 11 Canadian hospitals with 285 nurses working in 22 medical units. The internal consistency and validity testing showed a 0.89 alpha coefficient for the 26 items together, and a range of 0.61 to 0.70 for individual dimensions. The Principal Component Analysis for each dimension revealed $40 \%$ and $62 \%$ explained variances, indicating the coverage of each dimension by the component items (4).

Adapting the ASCOP for use in Lebanon was a first step in conducting a national study of the organization of nursing work in Lebanon and the impact of the organization of nursing work on the health of nurses. The study was approved by the Institutional Review Board of the American University of Beirut, and the Order of Nurses in Lebanon. WHO guidelines for the translation and adaptation of instruments were followed (7). The process involved forward translation, an expert panel, back-translation, pre-testing and cognitive interviewing. Permission to use and translate the ASCOP instrument was obtained from Dr D'Amour by e-mail correspondence. Translation and cultural validation of the A-ASCOP took place in two phases between August 2014 and March 2015 (Figure 1).

\section{Phase I Translation, expert panel endorsement,} and back translation.

First, the questionnaire was translated into Arabic by the first author who is a bilingual (Arabic/English) experienced healthcare professional and administrator. Second, a bilingual expert panel (faculty members teaching in the Nursing Administration track and Master's degree nurses working as research assistants) convened to review and correct the draft version of the A-ASCOP. Third, the A-ASCOP as amended by the expert panel was translated back into English by an independent bilingual nurse academic who is experienced in translating measurement scales into English, but had no prior knowledge of the ASCOP.

\section{Phase II cultural validation.}

Twelve nurses from different geographical and educational backgrounds were recruited for individual cognitive interviews conducted to validate the cultural appropriateness of the A-ASCOP. A graduate nursing student trained by a senior faculty in cognitive interviewing recruited interviewees when they visited the Order of Nurses in Lebanon (ONL) to pay their annual registration fees. The cognitive interviews were conducted at a private office at the ONL.

The cognitive interviews included a verbal probing method (to ask specific questions after the participant answersin order to seek furtherinformation) that entailed the following steps: Each item in the questionnaire was revisited with every participant for clarity of content and structure. The interviewer starts by reading the questions and response options exactly as they appear in the questionnaire. After the respondent answers, the interviewer record on a separate version of the questionnaire whether the respondent: (a) needed the interviewer to repeat any part of the question, (b) had any difficulty in choosing the answer options, or (c) asked for clarification. In case of a "yes" on any of those questions, the interviewer asks the respondent whether he/she think there is a better way to formulate or rephrase the question (Table 1). This method helps identify whether expressions that were translated with difficulty have equivalent cultural meaning with the original ones $(8,9)$.

\section{Data Analysis}

After each interview, the interviewer summarized the comments of the interviewee under each question. The interviewer and the first author then met to discuss the comments and describe the information taken into account before amending the A-ASCOP.

\section{Results}

\section{Phase I translation, expert panel endorsement, and back translation}

The findings of Phase I of the study clearly indicated that the A-ASCOP was not suitable for use following the initial translation. Of the 26 items, seven items $[3,5,6,7,8,13,17]$ 
Table 1 Cognitive interview probing questions

Did you need to ask for clarification or qualify your answer?
Did you have any difficulty using the response options?
Was there any word you did not understand?
Did you need to ask for a question to be rephrased?
In your own words, what does this question ask?
If it was up to you, how would you rephrase the question?
Was the question as put easy or hard to answer? Why?
Is there anything else you would like to say about the questions or the questionnaire?

confused the participants and did not preserve the meaning of the original ASCOP questionnaire. Although properly translated, five of the remaining items $[2,4,9,10,15]$ needed to be rephrased (Figure 1). The Expert Panel met with the first author to consider alternative phrasing of the 12 items that required revision, including rewording suggested by the participants. Amendments were made to the items that required improvement. Consensus was achieved on the rewording of all 12 items. The revised version of the A-ASCOP was approved by IRB on 6 November, 2014.

\section{Phase II cultural validation}

The sample consisted of eight registered nurses and four practical nurses. Five of the participants had a Bachelor of Sciences (BS) in nursing, three had Technique Supérieur (TS), two had Baccalaureate Technique (BT), and two participants had Brevet Pratique (BP) [an assistant nurse with 1 or 2 years training programme after 9th grade]. The sample was recruited from diverse locations of Lebanon; four nurses work in the south, three in Beirut, two in the north, and three at locations on Mount Lebanon. The

\begin{tabular}{|c|c|c|c|c|c|c|c|c|}
\hline \multirow[t]{2}{*}{ Study Phases } & \multicolumn{5}{|c|}{2014} & \multicolumn{3}{|c|}{2015} \\
\hline & Aug & Sep & Oct & Nov & Dec & Jan & Feb & Mar \\
\hline \multicolumn{9}{|l|}{ Phase 1} \\
\hline \multicolumn{9}{|l|}{$\begin{array}{l}\text { 1.1. English ASCOP translated into } \\
\text { Arabic (first draft of the A-ASCOP) }\end{array}$} \\
\hline \multicolumn{9}{|l|}{ 1.2. IRB approval } \\
\hline \multicolumn{9}{|l|}{ 1.3. Expert panel input (first cycle) } \\
\hline \multicolumn{9}{|l|}{ 1.4. Back translation of the A-ASCOP into English } \\
\hline \multicolumn{9}{|l|}{ 1.5. A-ASCOP updated on the basis of 1.4} \\
\hline \multicolumn{9}{|l|}{ 1.6. IRB approval of updated A-ASCOP } \\
\hline \multicolumn{9}{|l|}{ Phase 2} \\
\hline \multicolumn{9}{|l|}{ 2.1. Cognitive interviews } \\
\hline \multicolumn{9}{|l|}{ 2.2. Expert panel input (second cycle) } \\
\hline 2.3. IRB approval of final version of the A-ASCOP & & & & & & & & \\
\hline
\end{tabular}

\begin{tabular}{|c|c|c|c|}
\hline & & $\begin{array}{c}\text { Phase 1: } \\
\text { Translation and Back } \\
\text { translation }\end{array}$ & $\begin{array}{c}\text { Phase 2: } \\
\text { Focus Group Discussion }\end{array}$ \\
\hline Outcome of Interest & $\begin{array}{l}\text { Percent of unclear items } \\
\text { reported }\end{array}$ & Expert feedback & Nurses responses \\
\hline Unit of Analysis & Questionnaire Items & $\begin{array}{l}\text { Faculty \& } \\
\text { clinical practitioners }\end{array}$ & $\begin{array}{l}\text { Registered \& } \\
\text { Practical Nurses }\end{array}$ \\
\hline Data collection method & Checklist & Checklist & $\begin{array}{l}\text { Cognitive interviews + } \\
\text { Checklist }\end{array}$ \\
\hline Data collection tool & ASCOP questionnaire & ASCOP questionnaire & ASCOP questionnaire \\
\hline Sample & 26 questionnaire items & 5 Experts & 12 nurses \\
\hline
\end{tabular}


Figure 2 Percent of unclear items

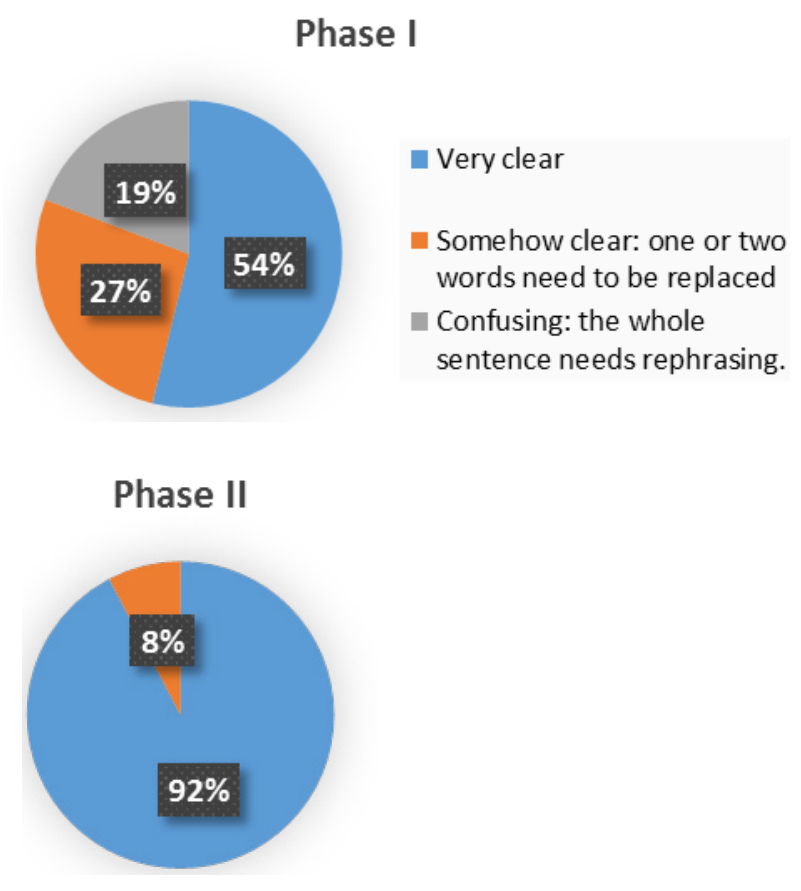

age of the participants ranged between 20 to 40 years, thereby providing input from nurses with different levels of nursing experience. Ten participants reported that A-ASCOP questions were very clear and did not need further amendment. Of the two participants who thought further amendment was required, one commented on items 11 and 21; the other on item 21 only (Figure 2). Suggested changes to the wording of items 11 and 21 were reviewed by the Expert Panel. The Expert Panel achieved agreement on the rewording of items 11 and 21 by consensus. The IRB approved the final version of the A-ASCOP (Appendix A) on March 16, 2015.

\section{Discussion}

Optimal nursing care requires a thorough assessment of patients' needs, appropriate selection of nursing interventions, and continuous monitoring and evaluation of patient status. In addition, nurses are required to coordinate and carry out treatments requested by other healthcare professionals, mainly physicians. The six dimensions of the ASCOP questionnaire address all the above mentioned nursing activities; for that reason it was adopted, translated, and culturally adapted to measure the actual scope of practice of Lebanese nurses.
The original ASCOP instrument targeted registered nurses (RNs) while the Arabic version was designed to be answered by nurses with different educational backgrounds (lower, at, or higher than RN position). All those involved in the translation and cultural validation of the A-ASCOP, including the participants were recruited for their bilingual competency and their expertise in the field of nursing education and practice. They were challenged to adopt clear, simple, and concise terms Arabic terms that could be understood by a nurse with any level of professional preparation. Accordingly, the cognitive interview sample included participants with typical levels of nursing preparation in Lebanon to make sure that all the items could be readily understood by nurses recruited for surveys of the actual scope of nursing practice in the region. The validation process of using a combination of steps (translation, panel input, back translation, and cognitive interviewing) assured multiple evaluations of both the semantic and idiomatic equivalence of the English and Arabic version.

A limitation of the translation and cultural validation process is that the sample size for the cognitive interview component was a small sample. However, similar small samples have been used in comparable studies (10). The second limitation is that the A-ASCOP cannot be properly validated without psychometric analysis. Our Arabic version of the scale has undertaken thorough psychometric analyses by the authors and the results will be published.

\section{Conclusion}

The Arabic version of the ASCOP questionnaire is a culturally adapted instrument that can be used to measure the actual scope of practice of Arabic speaking nurses working in short-term hospitals, subject to psychometric validation. It may also be valuable for any Middle-Eastern nurse administrator or policy maker who wants to update job descriptions and scope of practice guidelines for the nursing workforce. Investigators in the Region are encouraged to join us in conducting surveys with the A-ASCOP to examine its psychometric characteristics and applicability to nurse deployment and nurse workforce planning.

\section{Funding: None.}

Competing interests: None declared. 
Appendix A

استبيان" نطاق ممارسة المهنة

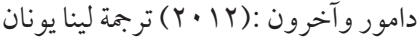

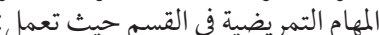

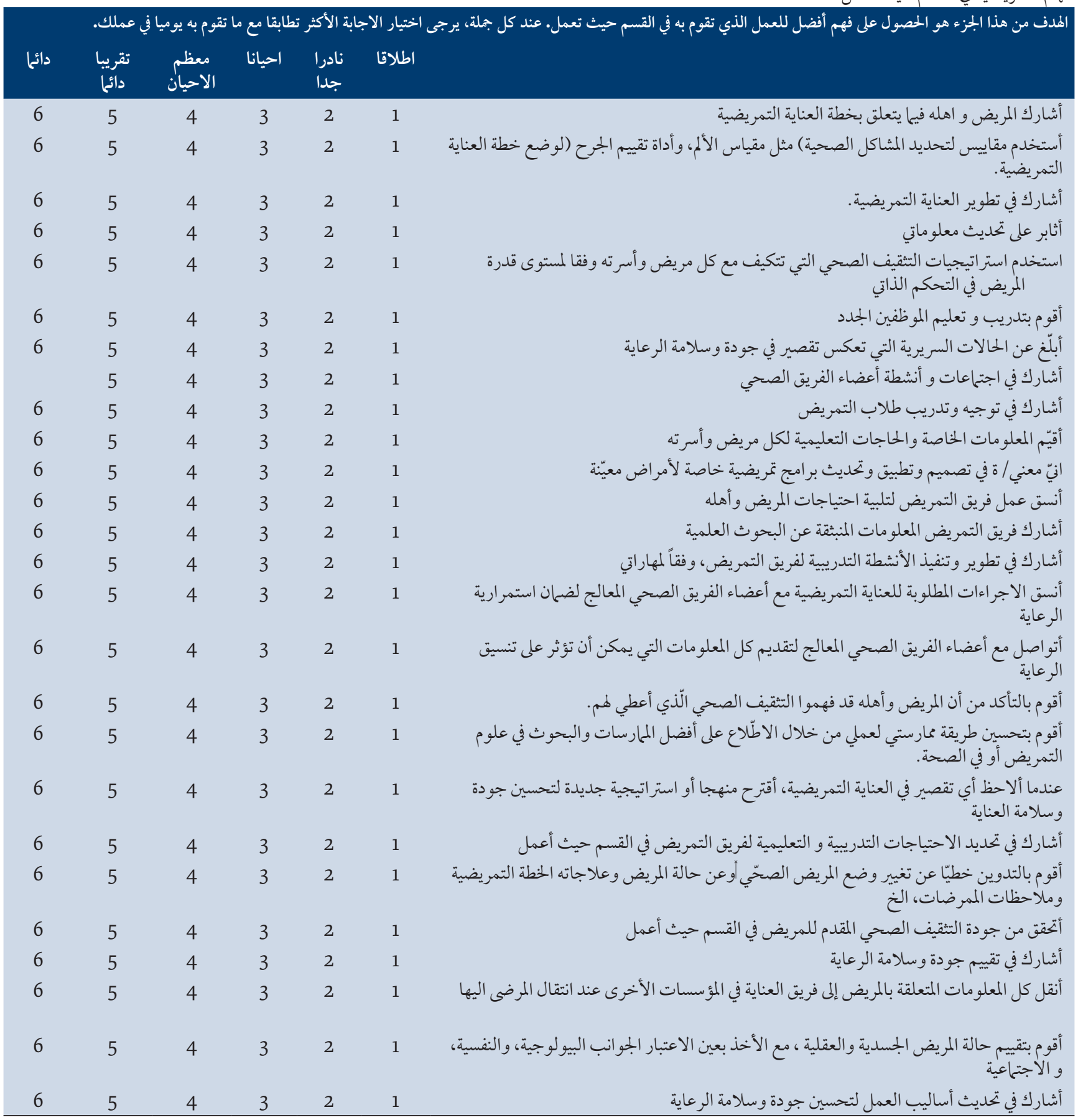


Appendix B

Functions of Registered nurse and nurse as stated in the Decree1655

Part one: Registered Nurse

Chapter one: Definition of the Registered Nurse and his/her functions

Article one: Definition of the Registered Nurse

$\mathrm{He} / \mathrm{she}$ is the person who has completed the study of a basic program in the field of nursing, and became qualified and certified to practice the nursing profession on the Lebanese territory, in view of his/her leadership and planning role in the field of nursing, in addition to his/her capabilities to work as a member in a medical team.

Article two: Functions of the Registered Nurse

1 - Exercise nursing duties within the scope of his/her studies, the general and specific nursing regulations, according to his/her abilities and scientific qualifications.

2 - Teach nursing students within the field of his work and provide health instructions.

3 - Contributing to the implementation of general health policies within the limits of his/her capabilities, responsibilities and functions; and suggest needed nursing services.

4 - Participating in the nursing research aiming at the development and advancement of these sciences.

\section{Part two: The nurse}

Chapter one: Definition and functions of the Nurse

Article five: Definition of the nurse and his/her functions.

$\mathrm{He} / \mathrm{she}$ is the person who has received scientific and technical preparation that enable him/her to provide general but not complex nursing care, and who works under the supervision of the registered nurse.

Article six: Functions of the Nurse

1-Knows the basic needs required by the people he/she is entrusted with their care.

2-Contribute in putting a program for the care of these people, along with his fellow staff.

3-Convey correct and accurate observations.

4-Implement instructions of the nurse-in-charge or the treating physician, with full awareness and caution.

5-Contribute with the other members of the medical body in the care of public health, prevention of disease, and rehabilitation of patients. 


\begin{tabular}{|c|c|c|c|}
\hline Dimensions & Level 1: Low complexity & Level 2: Moderate complexity & $\begin{array}{l}\text { Level 3: High } \\
\text { complexity }\end{array}$ \\
\hline $\begin{array}{l}\text { Assessment \& care } \\
\text { planning }\end{array}$ & $\begin{array}{l}\text { 25. I assess the patient's physical and mental } \\
\text { condition, taking biopsychosocial aspects into } \\
\text { consideration. } \\
\text { 21. I regularly update, in writing, information } \\
\text { about the patient's condition and the care provided } \\
\text { (therapeutic nursing plan, nurses' notes, etc). }\end{array}$ & $\begin{array}{l}\text { 1. I involve the patient and the } \\
\text { patient's family in care planning. } \\
\text { 2. To plan my interventions, I use } \\
\text { healthcare problem assessment tools } \\
\text { (pain scale, wound assessment tool). }\end{array}$ & $\begin{array}{l}\text { 11. I am involved in } \\
\text { designing, applying, and } \\
\text { updating patient care } \\
\text { programs. }\end{array}$ \\
\hline $\begin{array}{l}\text { Teaching of patients } \\
\text { and families }\end{array}$ & $\begin{array}{l}\text { 10. I assess the specific information and education } \\
\text { needs of each patient and his/her family. } \\
\text { 17. I verify that the patient and family have } \\
\text { understood the teaching provided. }\end{array}$ & $\begin{array}{l}\text { 5. I use teaching strategies that are } \\
\text { adapted to each patient and family in } \\
\text { accordance with the patient's level of } \\
\text { autonomy. }\end{array}$ & $\begin{array}{l}\text { 22. I check the quality of } \\
\text { patient education provided } \\
\text { on the unit. }\end{array}$ \\
\hline $\begin{array}{l}\text { Communication and } \\
\text { care coordination }\end{array}$ & $\begin{array}{l}\text { 16. I communicate to members of the team all } \\
\text { information that could affect the coordination of } \\
\text { care. }\end{array}$ & $\begin{array}{l}\text { 12. I coordinate the work of the } \\
\text { nursing team to meet the needs of } \\
\text { the patient and family. } \\
\text { 24. I convey all relevant information } \\
\text { to healthcare professionals in other } \\
\text { institutions in order to ensure } \\
\text { continuity of care. }\end{array}$ & $\begin{array}{l}\text { 8. I am involved in } \\
\text { Interprofessional team } \\
\text { meetings or activities. } 3 \\
\text { 15. To ensure continuity } \\
\text { of care, I coordinate the } \\
\text { interventions of the } \\
\text { Interprofessional team. }\end{array}$ \\
\hline $\begin{array}{l}\text { Integration and } \\
\text { supervision of staff }\end{array}$ & & $\begin{array}{l}\text { 20. I am involved in identifying in- } \\
\text { service education needs for my unit. } \\
\text { 9. I am involved in the orientation } \\
\text { and training of nursing students or } \\
\text { of newly hired staff. }\end{array}$ & $\begin{array}{l}\text { 6. I act as a mentor or } \\
\text { educator for newly hired } \\
\text { staff. } \\
\text { 14. I am involved } \\
\text { in developing and } \\
\text { conducting training } \\
\text { activities for the care team, } \\
\text { in accordance with my } \\
\text { skills. }\end{array}$ \\
\hline $\begin{array}{l}\text { Quality of care and } \\
\text { patient safety }\end{array}$ & $\begin{array}{l}\text { 7. I report clinical situations in which I see } \\
\text { deficiencies in quality and safety of care. }\end{array}$ & $\begin{array}{l}\text { 26. I get involved in updating } \\
\text { practices to improve the quality and } \\
\text { safety of care. } \\
\text { 19. When I have identified } \\
\text { deficiencies, I suggest approaches or } \\
\text { strategies to improve the quality and } \\
\text { safety of care. }\end{array}$ & $\begin{array}{l}\text { 23. I am involved in } \\
\text { evaluating the quality and } \\
\text { safety of care. } \\
\text { 3. I am involved in } \\
\text { developing nursing } \\
\text { practice. }\end{array}$ \\
\hline $\begin{array}{l}\text { Knowledge updating } \\
\text { and utilization }\end{array}$ & 4. I keep my knowledge up-to-date. & $\begin{array}{l}\text { 18. I improve my practice based on } \\
\text { new knowledge derived from best } \\
\text { practices and research in nursing } \\
\text { science or in health. }\end{array}$ & $\begin{array}{l}\text { 13. I share with the } \\
\text { nursing team knowledge } \\
\text { emerging from research. }\end{array}$ \\
\hline
\end{tabular}

(Adapted from the ASCOPE questionnaire items; D'Amour et al. 2012) 


\section{Validité de la traduction et de l'adaptation culturelle du Questionnaire de l'étendue de la pratique infirmière (QÉPI)}

\section{Résumé}

Contexte : Des informations sur l'étendue de la pratique infirmière sont requises de toute urgence dans la Région de la Méditerranée orientale afin d'aider les responsables politiques et les directeurs de services infirmiers à mettre au point des prévisions relatives aux effectifs du personnel en toute connaissance de cause.

Objectifs : La présente étude avait pour objectif de valider la traduction arabe et l'adaptation culturelle du Questionnaire de l'étendue de la pratique infirmière (QÉPI).

Méthodes : Le processus de traduction et de validation culturelle était conforme aux lignes directrices de l'OMS, et impliquait la traduction initiale, la révision par un panel d'experts, la production d'une rétro-traduction, un test préalable du questionnaire et la réalisation d'un entretien cognitif.

Résultats : La clarté, l'importance, et la pertinence de la première version arabe du QÉPI ont été validées.

Conclusion : Sous réserve de l'analyse psychométrique, le Questionnaire de l'étendue de la pratique infirmière est adapté à une utilisation au Liban et dans les pays de la région du Moyen-Orient.

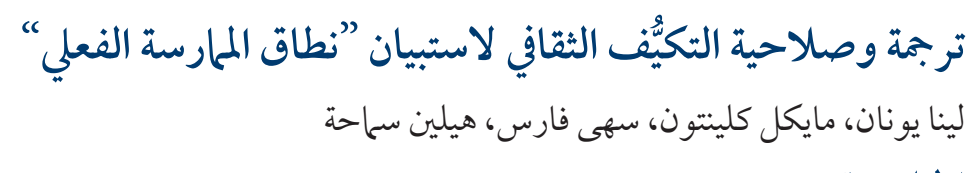

$$
\begin{aligned}
& \text { الخلفية: توجد حاجة ملّحة لجمع معلو مات بشأن نطاق ممارسة التمريض في إقليم شرق المتوسط من أجل مساعدة راسمي السياسات ومديري } \\
& \text { التمريض على وضع خطط مبنية على المعرفة للقوى العاملة. } \\
& \text { الأهداف: هدفت هذه الدر اسة إلى التحققّ من صحة الترجمة العربية لاستبيان ”نطاق الملمارسة الفعلي “وصلاحية التكيُّف الثقافي. }
\end{aligned}
$$

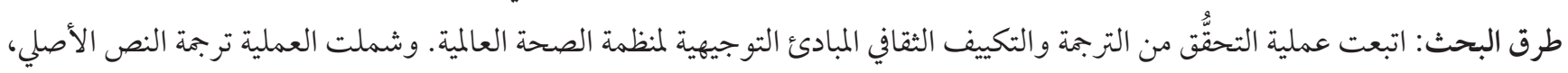

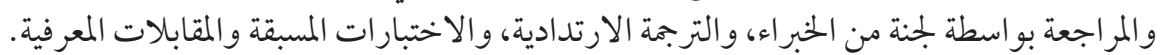

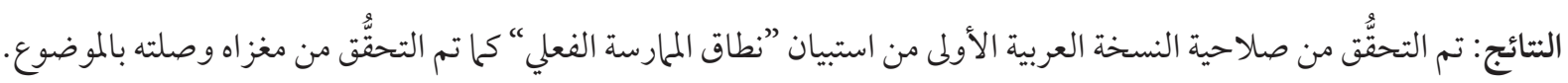

$$
\begin{aligned}
& \text { الاستنتاجات: وفقًا لتحليل القياس النفسي، يُعَدُّ استبيان "نطاق الملمارسة الفعلي، ، مناسبًا للاستخدام في لبنان وبلدان إقليم شرق المتوسط. }
\end{aligned}
$$

\section{References}

1. Jacob ER, McKenna L, D'Amore A. The changing skill mix in nursing: considerations for and against different levels of nurse. J Nurs Manag. 2015;23(4):421-6.

2. Déry J, Clarke S, D’Amour D, Blais R. Education and role title as predictors of enacted (actual) scope of practice in generalist nurses in a pediatric academic health sciences center. J Nurs Adm. 2016;45(5):265-70. PMID: 27046740 DOI: 10.1097/ NNA.0000000000000341

3. Lubbe JCI, Roets L. Nurses' scope of practice and the implication for quality nursing care. J Nurs Scholarsh. 2014;46(1):58-64. http://dx.doi.org/10.1111/jnu.12058

4. D'Amour D, Dubois CA, Dery J, Clarke S, Tchouaket E, Blais R, et al. Measuring actual scope of nursing practice. J Nurs Adm. 2012;42(5):248-55. http://dx.doi.org/10.1097/NNA.obo13e31824337f4

5. Ministry of Public Health. Regulation of the nursing profession decree 1655 amended by virtue of Law \# 82/10. Beirut, Lebanon. 1979.

6. El-Jardali F, Hammoud R, Younan L, Nuwayhid HS, Abdallah N, Alameddine M, et al. The making of nursing practice Law in Lebanon: a policy analysis case study. Health Res Policy Syst. 2014;12(52):1-15.

7. World Health Organization. Process of translation and adaptation of instruments. Geneva: World Health Organization; 2016 (http://www.who.int/substance_abuse/research_tools/translation/en/, accessed 20 September 2016).

8. Epstein J, Santo RM, Guillemin F. A review of guidelines for cross-cultural adaptation of questionnaires could not bring out a consensus. J Clin Epidemiol. 2015;68(4):435-41. http://dx.doi.org/10.1016/j.jclinepi.2014.11.021

9. Willis GB. Research synthesis the practice of cross-cultural cognitive interviewing. Public Opin Q. 2015;79 S1:359-95. http://dx. doi.org/10.1093/poq/nfuog2

10. Willis GB, Boeije H. Reflections on the Cognitive Interviewing Reporting Framework: Efficacy, expectations, and promise for the future. Methodol Eur J Res Methods Behav Soc Sci. 2013;9(3):123-8. http://dx.doi.org/10.1027/1614-2241/a0ooo74 